\title{
OCCURRENCE AND DISTRIBUTION OF THE ENDANGERED FRESHWATER MUSSELS UNIO CRASSUS AND PSEUDANODONTA COMPLANATA (BIVALVIA: UNIONIDA) IN THE PISA RIVER, NORTH-EASTERN POLAND
}

\author{
MAŁGORZATA OŻGO ${ }^{1 *}$, MARIA URbAŃSKA², MAGDALENA MARZEC ${ }^{3}$, ANDRZEJ KAMOCKI ${ }^{4}$ \\ ${ }^{1}$ Department of Evolutionary Biology, Kazimierz Wielki University, Al. Ossolińskich 12, \\ 85-093 Bydgoszcz, Poland (e-mail: mozgo.biol@interia.pl); (1) https://orcid.org/0000-0002-9999-8450 \\ ${ }^{2}$ Poznań University of Life Sciences, Wojska Polskiego 71C, 60-625 Poznań, Poland \\ (e-mail: maria.urbanska@up.poznan.pl); (i) https://orcid.org/0000-0003-1239-8231 \\ ${ }^{3}$ Suwalski Landscape Park, Malesowizna 24, 16-404 Jeleniewo, Poland \\ (e-mail: magdamarzec@poczta.onet.pl); (1) https://orcid.org/0000-0002-8366-6099 \\ ${ }^{4}$ Bialystok University of Technology, Wiejska 45E, 15-351 Białystok, Poland (e-mail: a.kamocki@pb.edu.pl); \\ (1) https://orcid.org/0000-0003-1375-8198 \\ *corresponding author
}

\begin{abstract}
Unionid mussels are among the most threatened groups of organisms globally. Habitat loss is one of the major drivers of their declines and local extinctions. In Poland six native species occur, but data on their present distribution are limited. The aim of this study was to assess unionid mussel species composition and distribution in the Pisa River, protected as part of Natura 2000 areas but currently threatened by plans of modification of its discharge regime and transformation into a navigable waterway. Twenty-one sites were surveyed using the timed-search method. The strictly protected Unio crassus was present at $86 \%$ of the sites and showed continuous distribution throughout the river. Young mussels constituted $26 \%$ of $U$. crassus individuals, indicating successful recruitment. Pseudanodonta complanata was found at three sites, suggesting that the Pisa River provides an important habitat also for this endangered species. Additionally, Anodonta cygnea, A. anatina, U. pictorum, and U. tumidus were recorded. Such multispecies unionid mussel communities are increasingly rare and need to be protected. The Pisa River is characterised by natural flow regime and a meandering channel with diversified depth and flow speeds. Conservation of $U$. crassus and other unionid mussels requires that its natural character is maintained and no changes are introduced into its channel.
\end{abstract}

KEY WORDS: endangered species, freshwater conservation, Natura 2000, the Pisa River, unionid distribution

\section{INTRODUCTION}

Freshwater mussels (Bivalvia: Unionida) suffer rapid population declines and range contractions throughout the world and belong to the most endangered groups of organisms globally (LYDEARD et al. 2004, LOPES-LIMA et al. 2017). The most important threats to their survival are habitat modification and pollution (LOPES-LIMA et al. 2018). Freshwater mussels are filter-feeding, relatively large-bodied, bottom-dwelling animals, with a larval stage (glochidium) that requires appropriate host fish. They play important roles in the functioning of aquatic ecosystems, contributing to water filtration and purification, nutrient cycling and storage, and bottom bioturbation (LUMMER et al. 2016, VAUGHN 2018, JOHNSON et al. 2019). Additionally, they are important ecosystem engineers modifying and creating 
habitats (VAUGHN \& HAKENKAMP 2001, GUTIÉRREZ et al. 2003, VAUGHN 2018). Declines and loss of unionid mussel populations lead to severe deterioration of the quality of freshwater habitats (HAAG \& WILIAMS 2014, VAUGHN 2018).

In Poland, six species of native unionid mussels occur, three of which are legally protected: the thick shelled river mussel Unio crassus Philipsson, 1788, the depressed river mussel Pseudanodonta complanata (Rossmässler, 1835), and the swan mussel Anodonta cygnea (Linnaeus, 1758). U. crassus is strictly protected with the requirement of active conservation (ROZPORZĄDZENIE 2014). All three species are listed in the Polish Red Data Book of Animals with the EN category - endangered (ZAJĄC 2004a, b, c). In the IUCN Red Data List, U. crassus is listed with the EN category and a decreasing population trend (LOPESLIMA et al. 2014), and P. complanata with the VU category (vulnerable) and an unknown population trend (VAN DAMME 2011); P. complanata is regarded as one of the most sensitive European unionid mussel species (ĆMIEL et al. 2019). U. crassus is included in Annexes II (species requiring designation of special protection areas) and IV (species requiring strict protection) of the Habitats Directive of the EU. Although the remaining three species: A. anatina (Linnaeus, 1758), U. pictorum (Linnaeus, 1758), and $U$. tumidus Philipsson, 1788 are not legally pro-

\section{MATERIAL AND METHODS}

\section{STUDY AREA}

The study was carried out in the southern section of the Pisa River, between its outflow from Lake Roś and the confluence with the Narew River (Fig. 1). The Pisa River is the main watercourse that drains waters from the catchment area of the Great Masurian Lakes. It originates in Lake Kisajno at the altitude of $158.9 \mathrm{~m}$ a. s. 1. and flows into the Narew River at the altitude of $95.7 \mathrm{~m}$ a. s. 1. (HYDROPORTAL 2019). The overall length of the Pisa is $147 \mathrm{~km}$, and its drainage basin covers an area of $4,507 \mathrm{~km}^{2}$. The width of the river channel varies from $10 \mathrm{~m}$ to $37 \mathrm{~m}$, and the average slope of the riverbed is $0.22 \%$. In its upper course the Pisa River flows through several Masurian Lakes and the riverine sections are relatively short. In its lower (southern) course, between Lake Roś and the Narew River, it is a largely natural, meandering, fast-flowing river, with diversified depth and flow-speeds. The length of this section of the Pisa is $82 \mathrm{~km}$, and the area of its drainage basin is $3,024 \mathrm{~km}^{2}$. The riverbed cuts into alluvial sediments, and the bottom is predominantly sandy or sandy with gravel and stones. The mean annual discharge recorded over the last five decades at the tected in Poland, in light of ongoing global declines of unionid mussels, changes in their distributions need to be documented as well. Some data on historical occurrence of unionid mussels in Poland are available (PIECHOCKI \& DYDUCH-FALNIOWSKA 1999, ZAJĄC 2004a, b, c, PIECHOCKI \& WAWRZYNIAKWYDROWSKA 2016), but the knowledge of their current distribution is limited.

Efficient protection and conservation of endangered species require that their distributions, abundances and changes in population condition are recognised (FERREIRA-RODRíGUEZ et al. 2019). This concerns especially the species that face an immediate threat of local extinctions resulting from habitat loss. In view of the increasing human pressure on freshwater habitats, documentation of the occurrence and distribution of freshwater biota is of the highest conservation priority. The current study was undertaken in response to the recently published plans of major hydrotechnical works on the Pisa River, including modifications of its discharge regime and transformation of the river into a navigable waterway (POLISH WATERS 2019). The aim of this paper is to document the occurrence and distribution of unionid mussels in the Pisa River with a focus on two endangered and legally protected riverine species: $U$. crassus and $P$. complanata.

gauging station in Ptaki village (approximately in the middle of the study area) is $21.2 \mathrm{~m}^{3} \mathrm{~s}^{-1}$. Basic physicochemical parameters of the surface water of the Pisa River were assessed in the summer 2014. The mean $( \pm \mathrm{SD}) \mathrm{pH}$ was $7.4 \pm 0.36$ and the electrical conductivity was $389 \pm 64.0 \mu \mathrm{S} \mathrm{cm}^{-1}(\mathrm{n}=32$, Hach Lange HQ40D). Water transparency was high, with Secchi depth equal to water depth at all sites (AK, unpublished data). In the second half of the 20th century, the tributaries of the lower course of the Pisa River (e.g. Rybnica, Wincenta, Skroda, and Turośl) were regulated and their valleys were drained. Fortunately, the Pisa River was left in its natural state, and it is currently protected as part of PLH280048 and PLH200023 Natura 2000 areas. Additionally, PLB280008 Nature 2000 area includes part of its course (Fig. 1). In spite of this, according to the "Drought Effects Counteracting Plan" of the National Agency Polish Waters, major hydrotechnical works are planned, including the construction of at least one weir damming the outflow from Lake Roś; ultimately, transformation of the Narew and Pisa Rivers into navigable waterways is planned (POLISH WATERS 2019). 


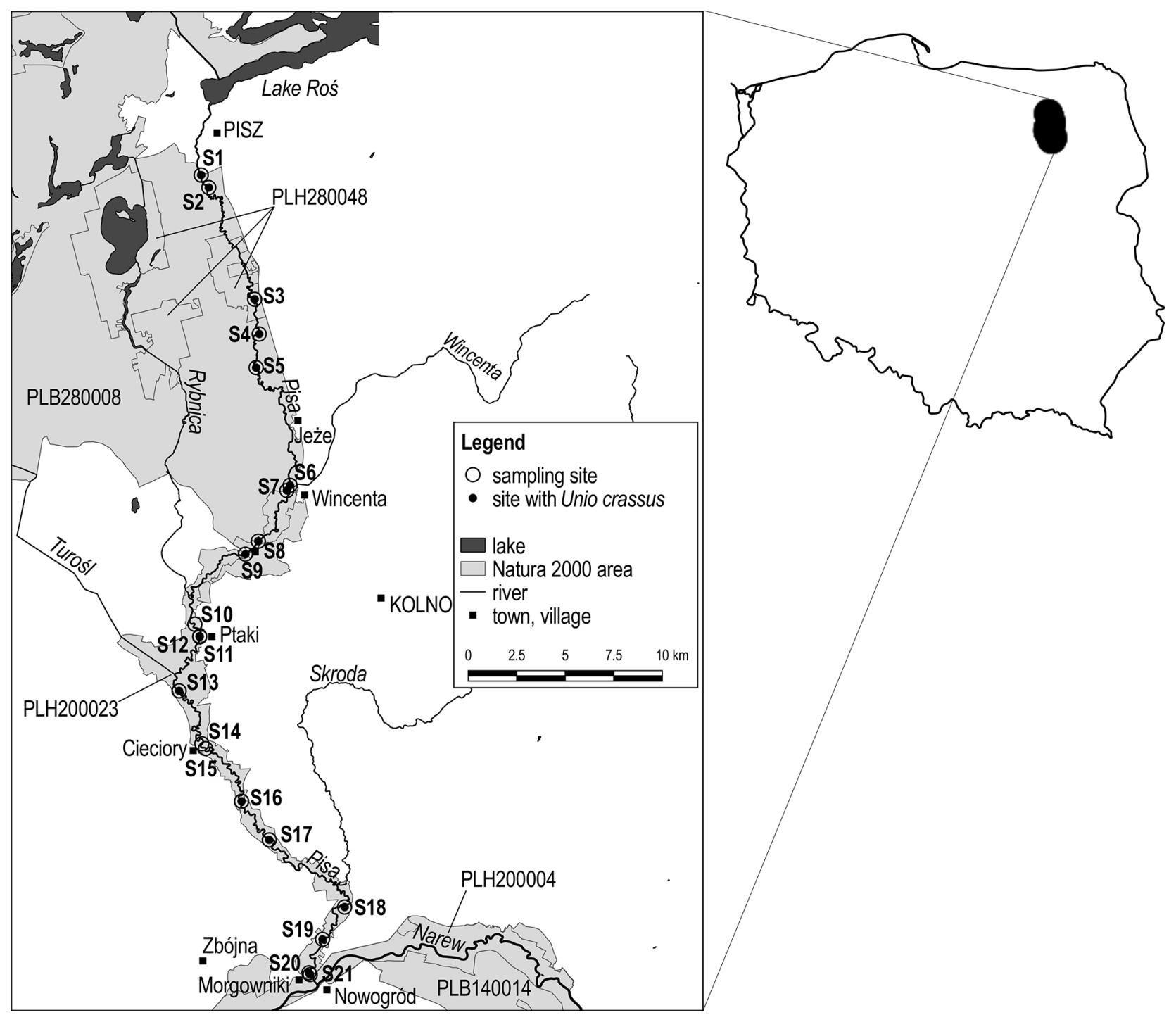

Fig. 1. Location of the study sites and results of the survey on the occurrence of $U$. crassus in the southern part of the Pisa River

\section{MUSSEL COLLECTION AND DOCUMENTATION}

The data were collected at study sites located along the southern section of the Pisa River, between its outflow from Lake Roś and its confluence with the Narew River (Fig. 1). The survey was carried out in August 2015 and August 2019. Mussels were collected by hand-sampling to a sediment depth of about $15 \mathrm{~cm}$ in places with water depth up to about $70 \mathrm{~cm}$, using the timed-search method (0.5 person-hour per site). In 2015, mussels were photographed on-site and species were identified from photographs. In 2019, species were identified on site. In U. crassus and $P$. complanata, individuals with four or less discernible annual growth rings were assigned to the young age-category. All mussels were returned to the places of collection. The position of the study sites was determined with a hand-held Garmin GPS receiver.

\section{RESULTS AND DISCUSSION}

U. crassus occurred throughout the studied area and was present at $86 \%$ of the study sites (Table 1). Figure 2 shows an example survey site and $U$. crassus individuals collected there. Young mussels, with up to four annual growth rings, were found at $46 \%$ of the sites in which $U$. crassus occurred, and con- stituted up to $26 \%$ of all of collected individuals of this species. $U$. crassus is a long-lived, slow-growing animal, with an individual life-span of up to 80 years (ZAJĄC 2004a). Counting external growth rings as a method of age estimation tends to underestimate the age of older individuals, but is reliable up to the 
Table 1. Number of individuals of $U$. crassus (Uc), P. complanata (Pc) and A. cygnea (Ac) found during 0.5 person-hour searches at each site; + indicates the presence of other unionid mussel species: A. anatina (Aa), U. pictorum (Up) and U. tumidus (Ut)

\begin{tabular}{|c|c|c|c|c|c|c|c|c|c|}
\hline Site & Study year & Coord & inates & Uc & $\mathrm{Pc}$ & Ac & $\mathrm{Aa}$ & Up & Ut \\
\hline S1 & 2019 & $53^{\circ} 36^{\prime} 24^{\prime \prime} \mathrm{N}$ & $21^{\circ} 48^{\prime} 27^{\prime \prime E}$ & 2 & & & + & + & + \\
\hline S2 & 2015 & $53^{\circ} 36^{\prime} 03^{\prime \prime} \mathrm{N}$ & $21^{\circ} 48^{\prime} 47^{\prime \prime E}$ & 20 & 2 & & + & + & + \\
\hline S3 & 2015 & $53^{\circ} 32^{\prime} 54^{\prime \prime} \mathrm{N}$ & $21^{\circ} 50^{\prime} 43^{\prime \prime} \mathrm{E}$ & 3 & & 3 & + & & + \\
\hline S4 & 2019 & $53^{\circ} 31^{\prime} 56^{\prime \prime} \mathrm{N}$ & $21^{\circ} 50^{\prime} 52^{\prime \prime} \mathrm{E}$ & 3 & 2 & & + & + & + \\
\hline S5 & 2015 & $53^{\circ} 30^{\prime} 60^{\prime \prime} \mathrm{N}$ & $21^{\circ} 50^{\prime} 39^{\prime \prime} \mathrm{E}$ & 1 & & & & + & + \\
\hline S6 & 2015 & $53^{\circ} 27^{\prime} 41^{\prime \prime} \mathrm{N}$ & $21^{\circ} 52^{\prime} 01^{\prime \prime E}$ & 4 & & & + & + & + \\
\hline S7 & 2019 & $53^{\circ} 27^{\prime} 33^{\prime \prime} \mathrm{N}$ & $21^{\circ} 51^{\prime} 51^{\prime \prime E}$ & 1 & & & + & + & + \\
\hline S8 & 2015 & $53^{\circ} 26^{\prime} 11^{\prime \prime} \mathrm{N}$ & $21^{\circ} 50^{\prime} 26^{\prime \prime} \mathrm{E}$ & 3 & & & + & & + \\
\hline S9 & 2019 & $53^{\circ} 25^{\prime} 50^{\prime \prime} \mathrm{N}$ & $21^{\circ} 49^{\prime} 49^{\prime \prime} \mathrm{E}$ & 3 & & & + & + & + \\
\hline S10 & 2015 & $53^{\circ} 23^{\prime} 56^{\prime \prime} \mathrm{N}$ & $21^{\circ} 47^{\prime} 20^{\prime \prime} \mathrm{E}$ & & & & + & + & + \\
\hline S11 & 2019 & $53^{\circ} 23^{\prime} 36^{\prime \prime} \mathrm{N}$ & $21^{\circ} 47^{\prime} 32^{\prime \prime} \mathrm{E}$ & 3 & & & + & + & + \\
\hline S12 & 2015 & $53^{\circ} 23^{\prime} 35^{\prime \prime} \mathrm{N}$ & $21^{\circ} 47^{\prime} 32^{\prime \prime} \mathrm{E}$ & 3 & & & + & & + \\
\hline S13 & 2015 & $53^{\circ} 22^{\prime} 06^{\prime \prime} \mathrm{N}$ & $21^{\circ} 46$ '29"E & 2 & & & + & + & + \\
\hline S14 & 2019 & $53^{\circ} 20^{\prime} 37^{\prime \prime} \mathrm{N}$ & $21^{\circ} 47^{\prime} 27^{\prime \prime E}$ & & & & + & + & + \\
\hline S15 & 2015 & $53^{\circ} 20^{\prime} 29^{\prime \prime} \mathrm{N}$ & $21^{\circ} 47^{\prime} 36^{\prime \prime} \mathrm{E}$ & & & & & & + \\
\hline S16 & 2015 & $53^{\circ} 18^{\prime} 59^{\prime \prime} \mathrm{N}$ & $21^{\circ} 49^{\prime} 11^{\prime \prime E}$ & 2 & & & & + & + \\
\hline S17 & 2015 & $53^{\circ} 17^{\prime} 52^{\prime \prime} \mathrm{N}$ & $21^{\circ} 50^{\prime} 24^{\prime \prime} \mathrm{E}$ & 3 & & & & & + \\
\hline S18 & 2015 & $53^{\circ} 15^{\prime} 55^{\prime \prime} \mathrm{N}$ & $21^{\circ} 53^{\prime} 46^{\prime \prime} \mathrm{E}$ & 3 & & & + & + & + \\
\hline S19 & 2015 & $53^{\circ} 15^{\prime} 03^{\prime \prime} \mathrm{N}$ & $21^{\circ} 52^{\prime} 40^{\prime \prime} \mathrm{E}$ & 3 & & & + & + & + \\
\hline S20 & 2015 & $53^{\circ} 14^{\prime} 08^{\prime \prime} \mathrm{N}$ & $21^{\circ} 51^{\prime} 59^{\prime \prime} \mathrm{E}$ & 1 & & & + & & + \\
\hline S21 & 2019 & $53^{\circ} 14^{\prime} 05^{\prime \prime} \mathrm{N}$ & $21^{\circ} 52^{\prime} 02^{\prime \prime} \mathrm{E}$ & 1 & 1 & & + & + & + \\
\hline
\end{tabular}

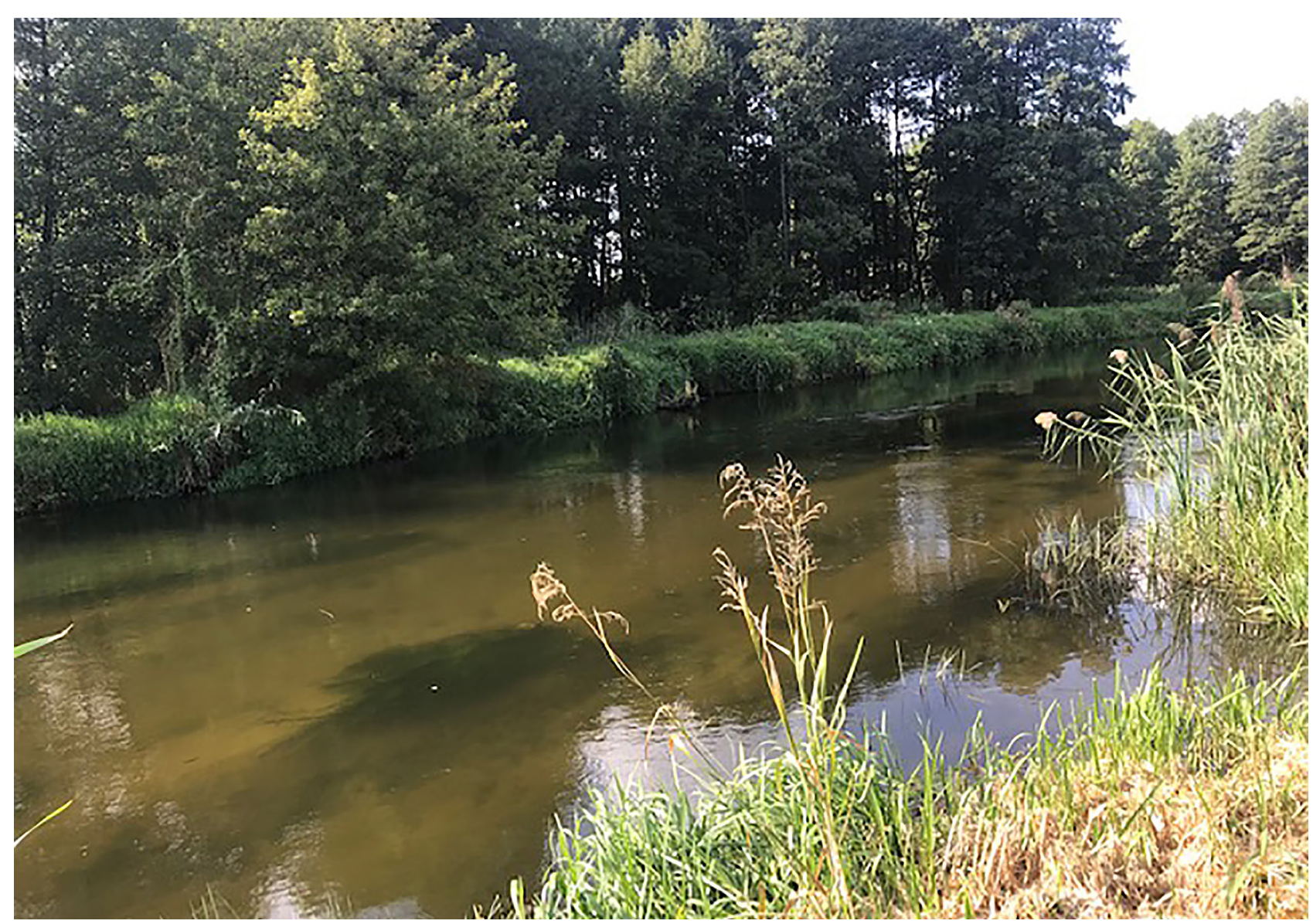

Fig. 2. The Pisa River at site S11 (August 2019). Photo: M. URBAŃSKA 
8th annual ring (NAGEL et al. 2015), and individuals with four or fewer annual growth rings can be safely assumed to represent recent recruiters in the population. Thus, the findings of this study documenting the wide distribution and ongoing processes of population renewal indicate a favourable conservation status of $U$. crassus and point to the high conservation importance of the Pisa River.

The presence of $U$. crassus was not detected at sites S10, S14 and S15. At sites S14 and S15 the densities of all mussel species were low, with only single individuals of A. anatina, $U$. tumidus and $U$. pictorum found at site S14, and of U. tumidus at site S15. This contrasted strongly with other river stretches surveyed in this study, where abundant unionid mussel com- munities were observed. Both these sites are within the river section close to Cieciory village, where bank revetments were carried out in 2013 (Fig. 4). This suggests that even a relatively mild intervention in the river channel can have long-lasting negative effects on the unionid mussel communities.

$P$. complanata was found at three of the study sites. This species usually occurs at low densities and lives buried deep in the sediments (SAARINEN \& TASKINEN 2003). As its detectability is generally low, the fact that it was found at three dispersed sites suggests that it probably also has a wide distribution in the Pisa River.

Unionid mussels show extensive inter- and intra-specific differences in their vertical distribution

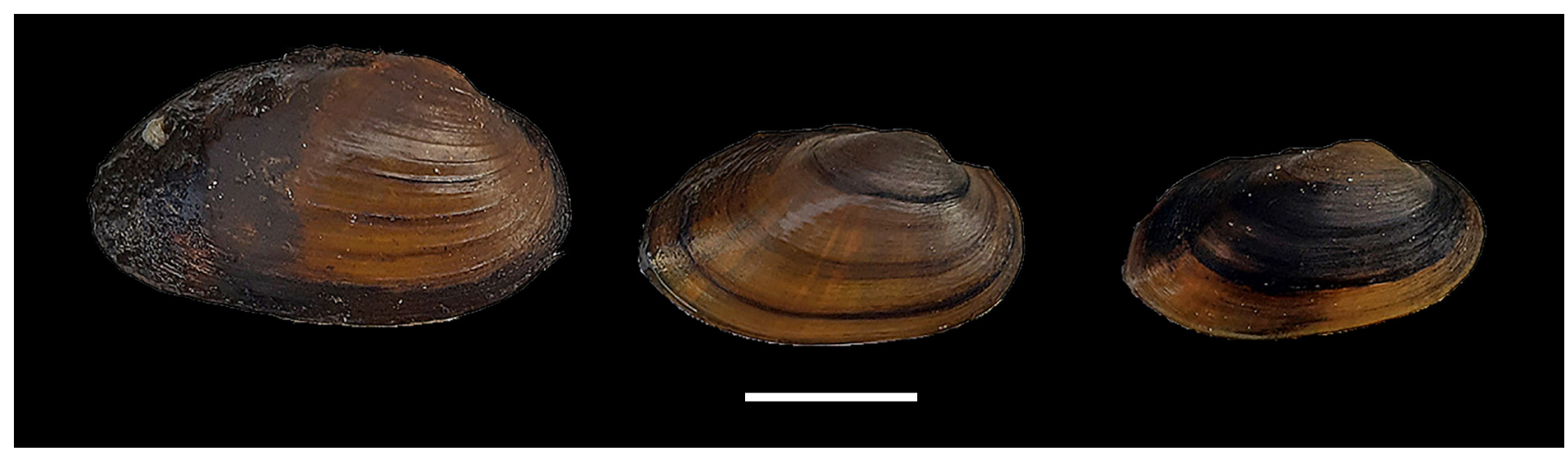

Fig. 3. U. crassus collected at site S11 (Ptaki on Pisa River, August 30th, 2019). Scale bar 20 mm. Photo: M. URBAŃSKA

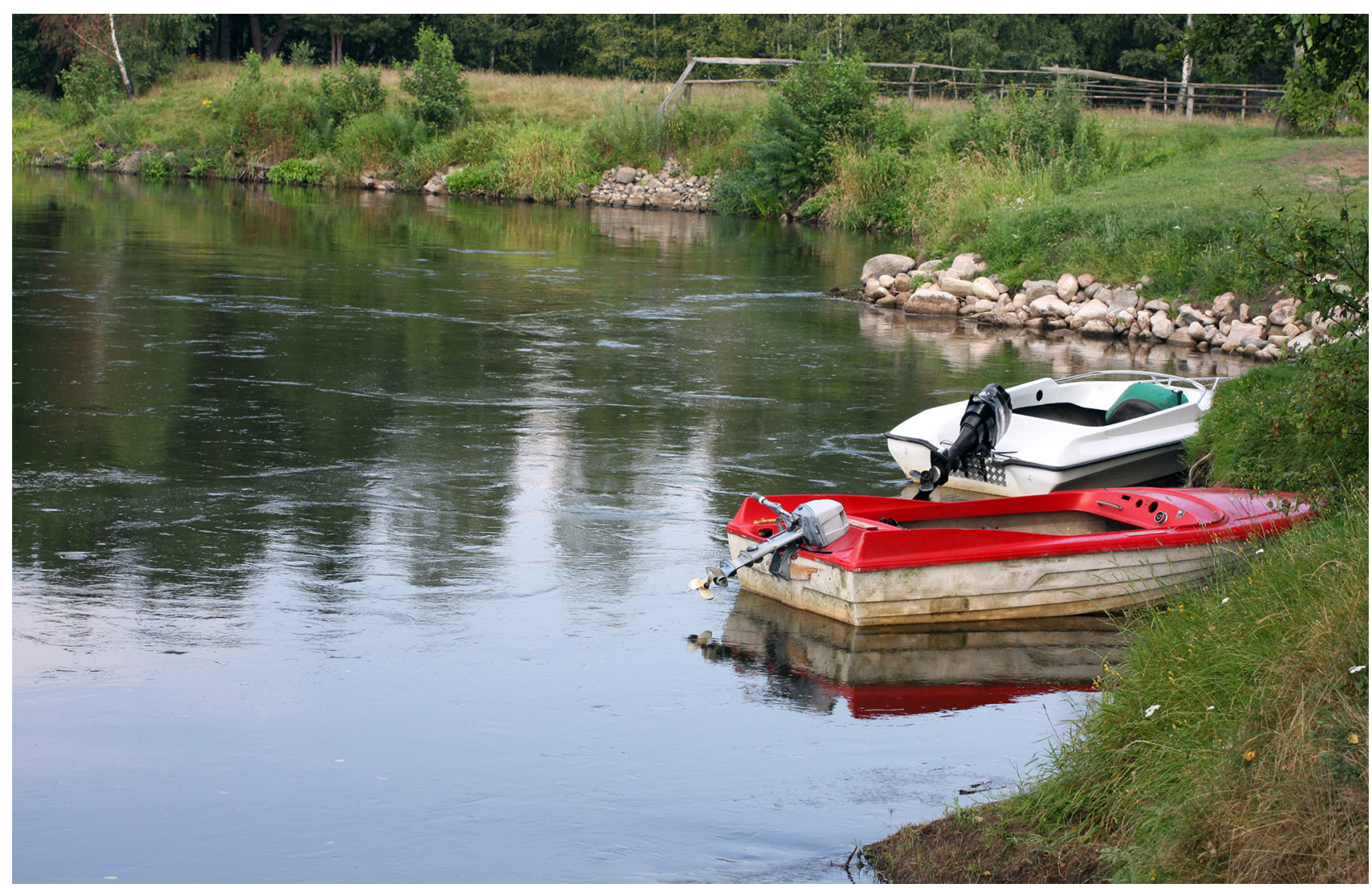

Fig. 4. Riverbank revetments made up of armour rock in the vicinity of Cieciory village (July 2014). Photo: A. KAMOCKI 
within sediments (SCHWALB \& PUSH 2007, PFEIFFER \& NAGEL 2010, ZIERITZ et al. 2014). In the 2019 survey, the majority of $U$. crassus and all P. complanata individuals were buried deep in the sediments, so that their siphons were not visible with an aquascope nor were they detectable by hand on the sediment surface. Such mussel behaviour may lead to an underestimation of their actual abundances.

\section{CONCLUSIONS}

The occurrence and favourable condition of $U$. crassus and $P$. complanata populations indicates a high conservation value of the Pisa River. This is further supported by the abundant occurrence of other unionid mussels: on the scale of Europe such multispecies mussel communities are increasingly rare, and need to be protected. The planned hydrotechnical works on the Pisa River are bound to have negative effects on the hydrology of the entire valley, and strong negative impacts on the ecological structure and functions of the habitats and species in the formally protected riverine ecosystems. In particular, the survival of the endangered species: $U$. crassus and $P$. complanata will be threatened.

Transformation of a natural river into a navigable waterway indispensably involves deepening of the river bed and straightening of the water course. Such river engineering has multiple, interconnected, often unintended and undesired socio-economic consequences, including increased downstream flooding risk, reduced fish productivity, and reduced aesthetic and recreational values (AUERSWALD et al. 2019). These consequences have to be considered and in-
Other unionid mussels occurred at high densities throughout the study area. U. tumidus occurred at all sites, A. anatina at 17 sites $(81 \%)$, U. pictorum at 15 sites $(71 \%), A$. cygnea at one site, and co-occurrence of four or five species was recorded at 12 (57\%) of the sites. Additionally, almost all individuals had smooth, uneroded shells, which points to their generally good condition and a high quality of the habitat.

cluded in the calculation of the costs of such investments. On the other hand, restoration of destroyed river habitats is complex, difficult and extremely expensive (AUERSWALD et al. 2019). Often the original state cannot be achieved, and only some of the ecosystem services can be recovered. Conserving high-quality near pristine habitats with their natural biodiversity and ecosystem processes is the best and the most cost-efficient option (GEIST \& HAWKINS 2016). Protection of the endangered mussel species, especially $U$. crassus, which is strictly protected in Poland and in Europe, requires that no changes are introduced into the river channel. This provides an additional argument for preserving the Pisa River in its natural state.

\section{ACKNOWLEDGMENTS}

We thank two anonymous reviewers for their helpful comments. The study was carried out in full compliance with the ethical codes and legislation of the Republic of Poland.

\section{REFERENCES}

Auerswald K., Moyle P., Seibert S. P., Geist J. 2019. HESS opinions: Socio-economic and ecological tradeoffs of flood management - benefits of a transdisciplinary approach. Hydrology and Earth System Sciences 23: 1035-1044. https://doi.org/10.5194/hess-231035-2019

ĆMIEL A. M., ZAJĄC K., LIPIŃSKA A. M., ZAJĄC T. 2019. Is Pseudanodonta complanata the most vulnerable of widespread European species of unionids? An intense stress test leading to a massive die off. Aquatic Conservation: Marine and Freshwater Ecosystems 1-8. https://doi. org/10.1002/aqc.3216

FERreira-Rodríguez N., AKIYAMA B. Y., AKSENOVA O., FERREIRA-RODRÍGUEZ N., AKIYAMA Y. B., AKSENOVA O. V., ARaujo R., Barnhart M. C., Bespalaya Y. V., Bogan A. E., Bolotov I. N., Budha P. B., Clavijo C., Clearwater S. J., DARrigran G., VAN T. D., DOUdA K., Froufe E., GumPINGER C., HENRIKSON L., HuMPHREY C. L., JOHNSON N. A., KLISHKO O., KLUNZINGER M. W.,

KOVITVADHI S., KOVITVADHI U., LAJTNER J., LOPESLima M., MOORKENS E. A., NAGAYAMA S., NAGEL K.O., NAKANO M., NEGISHI J. N., ONDINA P., OUlASVIRTA P., Prié V., RicCARdi N., Rudzīte M., SHELdON F., SOUSA R., STRAYER D. L., TAKEUCHI M., TASKINEN J., TEIXEIRA A., TIEMANN J. S., URBAŃSKA M., VARANDAS S., VINARSKI M. V., WICKLOW B. J., ZAJĄC T., VAUGHNAY C. C. 2019. Research priorities for freshwater mussel conservation assessment. Biological Conservation 231: 77-87. https://doi.org/10.1016/j.biocon.2019.01.002

GEIST J., HAWKINS S. J. 2016. Habitat recovery and restoration in aquatic ecosystems: Current progress and future challenges. Aquatic conservation: Marine and Freshwater Ecosystems 26: 942-962. https://doi. org/10.1002/aqc. 2702

Gutiérrez J. L., Jones C. G., Strayer D. L., Iribarne O. O. 2003. Mollusks as ecosystem engineers: the role of shell production in aquatic habitats. Oikos 101: 79-90. https://doi.org/10.1034/j.1600-0706.2003.12322.x 
HAAG W. R., WILliams J. D. 2014. Biodiversity on the brink: an assessment of conservation strategies for North American freshwater mussels. Hydrobiologia 735: 45-60. https://doi.org/10.1007/s10750-0131524-7

Hydroportal 2019. Mapa Podziału Hydrograficznego Polski w skali 1:10 000 https://wody.isok.gov.pl/imap_ $\mathrm{kzgw} /$ ?gpmap $=$ gpSIGW (accessed on 20 October 2019)

Johnson M. F., ThORnE C. R., CASTRO J. M., KondOlF G. M., Mazzacano C. S., RoOd S. B., WeStBRoOK C. 2019. Biomic river restoration: A new focus for river management. River Research and Applications, 2019: 1-10. https://doi.org/10.1002/rra.3529

Lopes-Lima M., Burlakova L. E., KaratayeV A. Y., MEHLER K., SEDDON M., SOUSA R. 2018. Conservation of freshwater bivalves at the global scale: diversity, threats and research needs. Hydrobiologia 810: 1-14. https://doi.org/10.1007/s10750-017-3486-7

LOPES-Lima M., KeBAPÇI U., VAN DAMme D. 2014. Unio crassus. The IUCN Red List of Threatened Species 2014: e.T22736A42465628. https://doi.org/10.2305/IUCN. UK.2014-1.RLTS.T22736A42465628.en (accessed on 30 September 2019)

Lopes-Lima M., Sousa R., GeIst J., Aldridge D. C., Araujo R., Bergengren J., Bespalaya Y., Bódis E., Burlakova L., VAN DAMME D., DOUDA K., Froufe E., GEORGIEV D., GUMPINGER C., KARATAYEV A., KEBAPÇI Ü., KilleEN I., LAJTNER J., LARSEN B. M., LAUCERI R., LEGAKIS A., LOIS S., LUNDBERG S., MOORKENS E., Motte G., Nagel K.-O., Ondina P., Outeiro A., PAUNOVIC M., PRIÉ V., PROSCHWITZ T. VON, RICCARDI N., Rudzīte M., Rudzītis M., SCHEdER C., SEDdON M., ŞEREFLIŞAN H., SIMIĆ V., SOKOlOVA S., STOECKL K., TASKINEN J., TEIXEIRA A., THIELEN F., TRICHKOVA T., VARANDAS S., ViCENTINI H., ZAJAC K., ZAJAC T., ZOGARIS S. 2017. Conservation status of freshwater mussels in Europe: state of the art and future challenges. Biological Reviews 92: 572-607. https://doi. org/10.1111/brv.12244

Lummer E. M., Auerswald K., Geist J. 2016. Fine sediment as environmental stressor affecting freshwater mussel behavior and ecosystem services. Science of the Total Environment 571: 1340-1348. https://doi. org/10.1016/j.scitotenv.2016.07.027

LydeARd C., CoWie R. H., PONDER W. F., BOGAN A. E., BOUChet P., Clark S. A., CUMmings K. S., Frest T. J., Gargominy O., Herbert D. G., Hershler R., Perez K. E., Roth B., Seddon M., Strong E. E., THOMPSON F. G. 2004. The global decline of nonmarine molluscs. Bioscience 54: 321-330. https://doi. org/10.1641/0006-3568(2004)054[0321:TGDON$\mathrm{M}] 2.0 . \mathrm{CO} ; 2$

NAGel K.-O., DümpelmanN C., PfeIfFer M. 2015. Effective growth cessation in adult $U$. crassus Philipson, 1788 (Bivalvia: Unionidae) from Germany. Folia Malacologica 23: 309-313. https://doi.org/10.12657/ folmal.023.027

Pfeiffer M., NAGEL K.-O. 2010. Schauen, tasten, graben - Strategien und Methoden für die Erfassung von Bachmuscheln (Unio crassus). Naturschutz und Landschaftsplanung 42: 171-179.

PieCHOCKI A., DyduCH-FAlNiOWSKA A. 1993. Mięczaki (Mollusca) - Małże (Bivalvia). Fauna Słodkowodna Polski 7A. Wydawnictwo Naukowe PWN, Warszawa.

PIECHOCKI A., WAWRZYNIAK-WYDROWSKA B. 2016. Guide to freshwater and marine Mollusca of Poland. Bogucki Wydawnictwo Naukowe, Poznań.

POLISH WATERS 2019. Projekt planu przeciwdziałania skutkom suszy. https://konsultacjesusza.pl/assets/ppss. pdf (accessed on 15 October 2019)

ROZPORZĄDZENIE 2014. Rozporządzenie Ministra Środowiska z dnia 6 października 2014 r. w sprawie ochrony gatunkowej zwierząt. Dz. U. z 2014 r. poz. 1348

SAARINEN M., TASKINEN J. 2003. Burrowing and crawling behaviour of three species of Unionidae in Finland. Journal of Molluscan Studies 69: 81-86. https://doi. org/10.1093/mollus/69.1.81

SCHWAlB A. N., PusCH M. T. 2007. Horizontal and vertical movements of unionid mussels in a lowland river. Journal of the North American Benthological Society 26: $261-272$.

VAN DAMME D. 2011. Pseudanodonta complanata. The IUCN Red List of Threatened Species 2011: e. T18446A8279278. https://doi.org/10.2305/IUCN. UK.2011-2.RLTS.T18446A8279278.en (accessed on 30 September 2019).

VAUGHN C. C. 2018. Ecosystem services provided by freshwater mussels. Hydrobiologia 810: 15-27. https://doi. org/10.1007/s10750-017-3139-X

VAUGHN C. C., HAKENKAMP C. C. 2001. The functional role of burrowing bivalves in freshwater ecosystems. Freshwater Biology 46: 1431-1446. https://doi. org/10.1046/j.1365-2427.2001.00771.x

ZAJĄC K. 2004a. Unio crassus. Polish Red Data Book of Animals. Invertebrates. http://www.iop.krakow.pl/ pckz/opis00d8.html?id=130\&je $=$ en (accessed on 30 September 2019).

ZAJĄC K. 2004b. Pseudanodonta complanata. Polish Red Data Book of Animals. Invertebrates. http://www.iop. krakow.pl/pckz/opis1f5b.html?id $=129 \& j e=e n \quad($ accessed on 30 September 2019).

ZAJĄC K. 2004c. Anodonta cygnea. Polish Red Data Book of Animals. Invertebrates. http://www.iop.krakow.pl/ pckz/opis325f.html? $\mathrm{id}=128 \& \mathrm{je}=\mathrm{en}$ (accessed on 30 September 2019).

ZIERITZ A., GEIST J., GUM B. 2014. Spatio-temporal distribution patterns of three stream-dwelling freshwater mussel species: towards a strategy for representative surveys. Hydrobiologia 735: 123-136. https://doi. org/10.1007/s10750-014-1897-2

Received: October 22nd, 2019

Revised: December 2nd, 2019

Accepted: December 5th, 2019

Published on-line: February 21st, 2020 